\title{
Experimental Studies on Compressive Strength of Aerated Concrete with Varying Percentage of Aluminium Powder
}

\author{
G.V.V. SATYANARAYANA ${ }^{1}$ and $A$. RANJITH \\ ${ }^{1}$ Professor, Dept. of Civil Engineering, GRIET, Hyderabad \\ 2 P.G.Scholar, Department of Civil Engineering, Hyderabad
}

\begin{abstract}
Today the disposal of various by-product materials is a concern against the environment, these are producing due to rapid industrial growth in our country. Most of the researchers are focused on the utilization of these by-products in the civil engineering construction industry. By using these by-products, on one hand, will protect the environment and other hands the disposal problem will be solved. Day by day the requirement of building materials increased due to urbanization, due to this more raw materials are required and depleted the natural resources. In this contest, environmental protection is need to protect incremental temperature in nature. To avoid these problems of the modern era, aggregation of these byproducts can be used as one of building material and to overcome this situation, Aerated concrete is one of the solutions by reducing the raw material quantity in concrete like sand and cement by introducing air without compromising in the volume. Day to day aerated concrete has become popular due to lightweight and high insulation against temperature and sound. This concrete is using in high raised buildings to reduce the self-weight of building to protect during earthquake situations. In this experimental study mainly performed the compressive strength of aerated concrete with replacement of sand by quarry dust. Also reducing the cement content with replacement of fly ash, GGBS and lime powder at various percentages that is ranging. the performance of aerated concrete was observed more satisfactory when compared with and without replacement of above-saided materials.
\end{abstract}

\section{INTRODUCTION}

The Construction industry deals with different types of concrete-like cement concrete, geo polymer concrete and fibrous concrete etc. Among them, aerated concrete is obtained by introducing admixtures like aluminium and zinc powders. Aeration of concrete can be done in two ways that are physically introducing air is one method and another one is by adding foaming agents. In aerated concrete, a chemical reaction takes place between calcium silicate hydrate gel(C-S-H) and aluminium powder produces hydrogen gas in it. This hydrogen gas escapes during the curing process and makes a maximum percentage of pores in aerated concrete blocks. Sohani N. Jani et al. [1,2] explained about the process and chemical reactions that occurs during the reaction of calcium silicate hydrate gel and aluminium powder in aerated concrete. Due to the addition of these chemicals which create tiny pores throughout structure it creates light in weight and frost resistance product. Aerated concrete improves thermal and sound insulation properties. Due to this aerated concrete has become popular in uses of exposed surface area. Anurag Wahane [3] compared autoclave aerated concrete with clay bricks and concluded that clay bricks weigh more than $80 \%$ of autoclave aerated concrete blocks also resulting in decrement during an earthquake. Most of the self-weight in buildings due to
* Corresponding author: ranjithrd1x@gmail.com walls and slabs etc, the usage of lightweight concretes like aerated, foam concretes can reduce the self-weight. AAC blocks with low density make the cost of building effectively with using AAC walls direct we can get steel requirement will be low in buildings. and also, in the case of high-rise buildings if we use ordinary burnt clay bricks there is a requirement of additional spandrel beams on the outer circumference so that these beams can carry loads of walls. Dr. G.V.V. Satyanarayana and G. Praveen Kumar [4] stated that the compressive strength of foam concrete depends on the density of foam concrete. The requirement of space needed for curing is less and low energy consumption. in the present scenario, it is one of the most popular building materials. Hari Sankar et al. [5] concluded that more absorption of water by aerated concrete blocks compared to ordinary clay bricks because the presence of more voids in them and also compressive strength of aerated concrete blocks reduced by $33 \%$ when blocks completely saturated. Satish Kumar [6] compared the compressive strength of AC blocks with hollow clay brick and recommended that AC block is better compared to hollow clay brick in strength criteria. And also, the strength of AC block depends on void size, curing process. J. Srinu Naik et al. [7,8] explained the strength variation with pore size. Jagadish Vengala et al. [9] 
concluded that immediate cooling of AAC blocks from 1500 degrees to room temperature results in a $35 \%$ reduction in strength.

\section{MATERIALS}

Detailed information about materials used in this experiment were listed below.

\subsection{CEMENT}

Present study deals with ordinary Portland cement of grade 53. Properties of ordinary Portland cement are shown in below table.

Table 1. properties of cement

\begin{tabular}{|c|c|c|c|}
\hline S.NO & PROPERTY & $\begin{array}{c}\text { OBTAINED } \\
\text { VALUE }\end{array}$ & $\begin{array}{c}\text { LIMITING } \\
\text { VALUES } \\
\text { AS PER IS } \\
\mathbf{( 1 2 2 6 9 -} \\
\mathbf{1 9 8 7 )} \\
\text { CODE }\end{array}$ \\
\hline 1 & $\begin{array}{c}\text { Fineness of } \\
\text { cement }\end{array}$ & $6 \%$ & $\begin{array}{c}\text { Less than } \\
10 \%\end{array}$ \\
\hline 2 & $\begin{array}{c}\text { Specific } \\
\text { gravity of } \\
\text { cement }\end{array}$ & 3.15 & $3.1-3.25$ \\
\hline 3 & $\begin{array}{c}\text { Consistency } \\
\text { of cement }\end{array}$ & $32 \%$ & $26 \%-35 \%$ \\
\hline 4 & $\begin{array}{c}\text { Initial setting } \\
\text { time of } \\
\text { cement }\end{array}$ & 50 minutes & $\begin{array}{c}\text { Not less } \\
\text { than } 30 \\
\text { minutes }\end{array}$ \\
\hline 5 & $\begin{array}{c}\text { Final setting } \\
\text { time of } \\
\text { cement }\end{array}$ & 280 minutes & $\begin{array}{c}\text { Not less } \\
\text { than } 10 \\
\text { hours }\end{array}$ \\
\hline 6 & $\begin{array}{c}\text { Compressive } \\
\text { strength after } \\
28 \text { days in } \\
\text { MPa }\end{array}$ & 56 & $\begin{array}{c}\text { Not less } \\
\text { than } 53 \mathrm{Mpa}\end{array}$ \\
\hline & & \\
\hline
\end{tabular}

\subsection{GROUND GRANULATED BLAST FURNACE SLAG}

It is obtained as by-product of iron industry in the process of purifying pig iron. It improves durability of concrete by acting protection against sulphate attack.

Table 2. properties of GGBS

\begin{tabular}{|c|c|c|}
\hline S.NO & PROPERTY & TEST RESUILTS \\
\hline 1 & Appearance & White in colour \\
\hline 2 & Specific gravity & 2.8 \\
\hline 3 & $\begin{array}{c}\text { Bulk density } \\
\left(\frac{\mathrm{kg}}{\mathrm{m}^{3}}\right)\end{array}$ & 1260 \\
\hline
\end{tabular}

\subsection{ALUMINIUM POWDER}

It is the major component of aerated concrete it introduces air bubbles in concrete. It is silver in colour and has very high concentration of pungent smell.

\subsection{FLY ASH}

In this experimental investigation class-F fly ash used as replacement of some amount of cement. It is collected from nearby RMC plant. It has at least $70 \%$ pozzolanic property.

Table 3. physical properties of fly ash of Grade 1

\begin{tabular}{|c|c|c|}
\hline S.NO & PROPERTY & $\begin{array}{c}\text { TEST } \\
\text { RESULTS }\end{array}$ \\
\hline 1 & $\begin{array}{c}\text { Fineness of fly } \\
\text { ash }\left(\frac{\mathrm{m}^{2}}{\mathrm{~kg}}\right)\end{array}$ & 270 \\
\hline 2 & $\begin{array}{c}\text { Specific gravity } \\
\text { of fly ash }\end{array}$ & 2.08 \\
\hline 3 & Size range & 10 to 100micron \\
\hline 4 & Colour & Light Gray \\
\hline
\end{tabular}

\subsection{QUARRY DUST}

Table 4. properties of quarry dust

\begin{tabular}{|c|c|c|}
\hline S.NO & PROPERTY & $\begin{array}{c}\text { TEST } \\
\text { RESULTS }\end{array}$ \\
\hline 1 & Specific gravity & 2.6 \\
\hline 2 & Bulk density $\left(\frac{\mathrm{kg}}{\mathrm{m}^{3}}\right)$ & 1780 \\
\hline
\end{tabular}

\section{METHODOLOGY}

In this study, the aerated concrete was produced with varying percentages of aluminium powder and replaced cement and sand with different mineral admixtures like fly ash, GGBS. By trial-and-error process, the mix proportion was fixed to achieve the required compressive strength. During the experimental stage, $100 \mathrm{~mm}$ size cubes are used for moulding. So much care is taken during the production of aerated concrete and moulding as well as unmoulding. Materials used for this test are cement, fly ash, ground granulated blast furnace slag, aluminium powder, limestone powder and water. These materials are mixed in proper proportions based on the trial-and-error process. After adding all these materials, they are mixed with varying content of aluminium powder of range 0.05 to $0.2 \%$ according to requirement and for about 2 to 5 minutes mixed with water to form a uniform consistency paste. Before pouring this paste, a layer of grease is applied to moulds so that paste cannot stick to moulds. Then paste is poured in moulds of $100 * 100 * 100 \mathrm{~mm}$ cubes. According to the height of pouring in each mould, the initial height should be noted immediately and marking of each mould corresponding to aluminium content and height of pouring is done simultaneously then after some time, the height of the sample varies according to the concentration of materials in each mould. After one day final height should be noted. Then these samples are cured in water for about 28 days to gain strength and to avoid cracks. The temperature of water used to cure the samples is of range 27 to 35 degrees and should be free from chemicals. After 28 days these samples are collected from water curing then placed in the oven drying for about 10 hours or samples are kept in the oven drying machine up to a weight of samples that should not be differing by 1 gram. Before testing the compressive strength of these samples weight of each sample should be noted using final 
volume, density is calculated. these samples are further used for the compressive test. In a compression test, each sample is placed and load is applied gradually. reading corresponding to failure should be noted and recorded in a notebook.

\section{MIX DESIGN}

Aerated concrete has no proper mix design but it has a strength range corresponding to target density. So aerated concrete is designed according to density class. The present study deals with the trial-and-error method to find the appropriate material quantities for designated density. After several attempts of material alterations and their quantities. The Final and fixed material proportions for good strength and density are obtained. Final mix proportion of cubes as follows, cement: fly ash: GGBS: quarry dust; lime powder (1:1:0.32:0.32:0.32). Aluminium powder is added to this mix of $0.05,0.1,0.15,0.2 \%$ and water taken for this mix is 0.4 percentage of the total mix weight.

\subsection{TEST PROCEDURE}

The steps involved in the preparation of cubes and testing of cubes are shown in figures below.

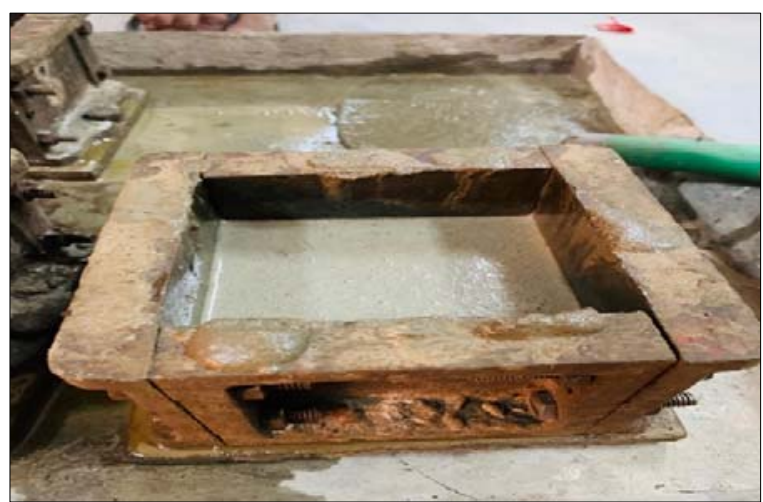

Fig. 1 wet aerated concrete specimen before expansion

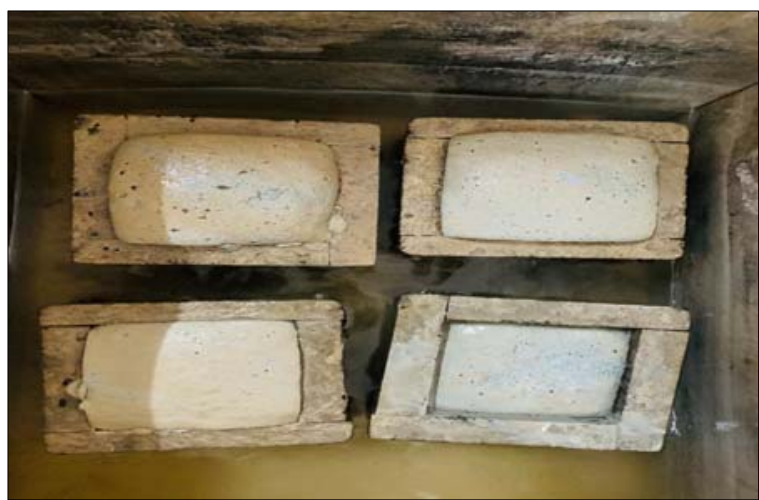

Fig. 2. Solidified and expanded cubes of aerated concrete

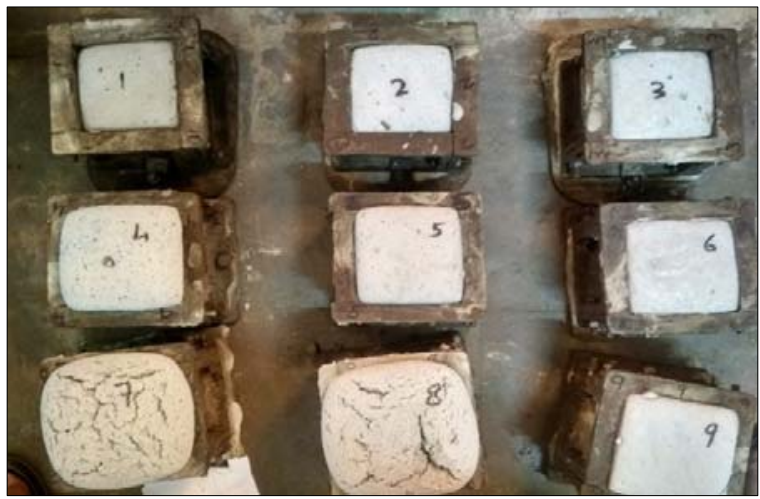

Fig. 3. Specimens of Different proportions of aluminium powder.

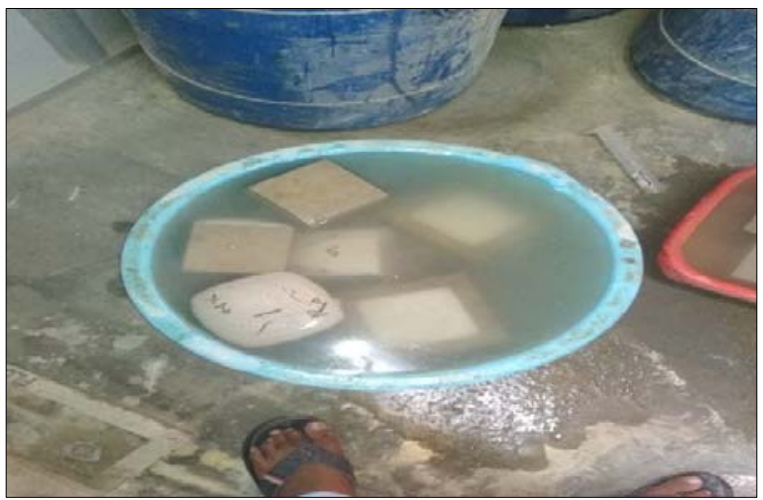

Fig. 4. Water curing of aerated concrete specimens

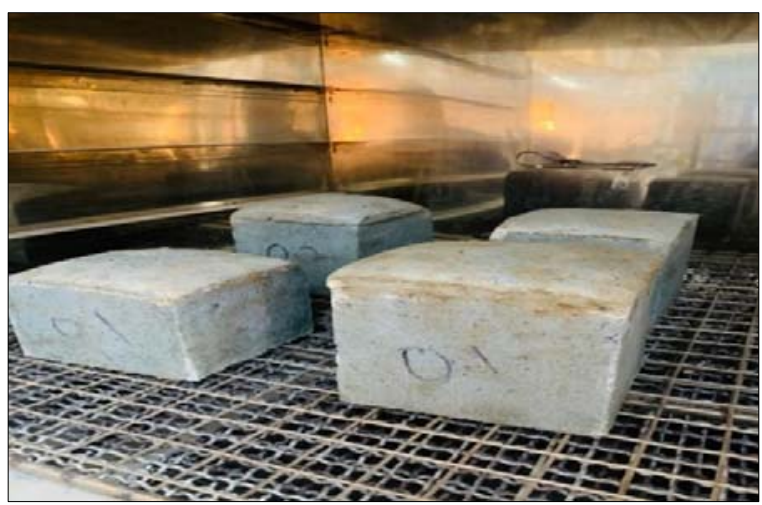

Fig. 5. Oven drying of samples before testing for compression test

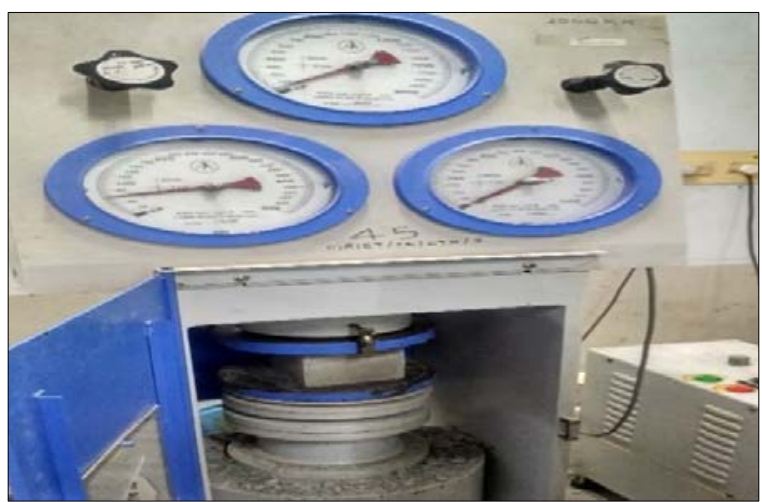

Fig. 6. Compression testing of specimens 


\section{EXPERIMENTAL RESULTS}

\subsection{DATA OF VOLUME EXPANSION}

Volume expansion of these cubes are taken after fresh mix has stopped expansion anymore. It usually takes three to four hours after fresh mix poured in moulds. Final expansion height (in $\mathrm{mm}$ ) is taken to determine dry density of samples.

Table 5. $0.05 \%$ of aluminium powder vs $\%$ additional volume change

\begin{tabular}{|c|c|c|c|}
\hline $\begin{array}{c}\text { ALUMINIUM } \\
\text { POWDER }\end{array}$ & $\begin{array}{c}\text { INITIAL } \\
\text { HEIGHT } \\
\text { IN }(\mathbf{m m})\end{array}$ & $\begin{array}{c}\text { FINAL } \\
\text { HEIGHT } \\
\text { IN (mm) }\end{array}$ & $\begin{array}{c}\text { VOLUME } \\
\text { CHANGE } \\
\text { IN } \mathbf{( \% )}\end{array}$ \\
\hline \multirow{2}{*}{$\begin{array}{c}0.05 \\
\text { Percentage }\end{array}$} & 8 & 10.4 & 30 \\
\cline { 2 - 4 } & 8.3 & 10.6 & 27.7 \\
\cline { 2 - 4 } & 7.7 & 10.2 & 32.46 \\
\hline
\end{tabular}

Table 6. $0.1 \%$ of aluminium powder vs $\%$ additional volume change

\begin{tabular}{|c|c|c|c|}
\hline $\begin{array}{c}\text { ALUMINIUM } \\
\text { POWDER }\end{array}$ & $\begin{array}{c}\text { INITIAL } \\
\text { HEIGHT } \\
\text { IN (mm) }\end{array}$ & $\begin{array}{c}\text { FINAL } \\
\text { HEIGHT } \\
\text { IN (mm) }\end{array}$ & $\begin{array}{c}\text { VOLUME } \\
\text { CHANGE } \\
\text { IN (\%) }\end{array}$ \\
\hline \multirow{2}{*}{0.1 Percentage } & 7.2 & 11.2 & 55.55 \\
\cline { 2 - 4 } & 8 & 11.8 & 47.5 \\
\cline { 2 - 4 } & 7.5 & 10.9 & 45.333 \\
\hline
\end{tabular}

Table 7. $0.1 \%$ of aluminium powder vs $\%$ additional volume change

\begin{tabular}{|c|c|c|c|}
\hline $\begin{array}{c}\text { ALUMINIUM } \\
\text { POWDER }\end{array}$ & $\begin{array}{c}\text { INITIAL } \\
\text { HEIGHT } \\
\text { IN (mm) }\end{array}$ & $\begin{array}{c}\text { FINAL } \\
\text { HEIGHT } \\
\text { IN (mm) }\end{array}$ & $\begin{array}{c}\text { VOLUME } \\
\text { CHANGE } \\
\text { IN (\%) }\end{array}$ \\
\hline \multirow{2}{*}{$\begin{array}{c}0.15 \\
\text { percentage }\end{array}$} & 8 & 12.9 & 61.25 \\
\cline { 2 - 4 } & 8 & 12.6 & 57.5 \\
\cline { 2 - 4 } & 7.5 & 12.2 & 62.66 \\
\hline
\end{tabular}

Table 8. $0.1 \%$ of aluminium powder vs $\%$ additional volume change

\begin{tabular}{|c|c|c|c|}
\hline $\begin{array}{c}\text { ALUMINIUM } \\
\text { POWDER }\end{array}$ & $\begin{array}{c}\text { INITIAL } \\
\text { HEIGHT } \\
\text { IN (mm) }\end{array}$ & $\begin{array}{c}\text { FINAL } \\
\text { HEIGHT } \\
\text { IN (mm) }\end{array}$ & $\begin{array}{c}\text { VOLUME } \\
\text { CHANGE } \\
\text { IN (\%) }\end{array}$ \\
\hline 0.2 percentage & 7 & 14.1 & 101.42 \\
\cline { 2 - 4 } & 7.5 & 13.6 & 81.33 \\
\cline { 2 - 4 } & 8 & 14.5 & 81.25 \\
\hline
\end{tabular}

\subsection{COMPRESSIVE STRENGTH}

Compressive strengths of all cubes are taken after 28 days. These all specimens are tested under compression testing machine based on requirements of IS code14858(2000).

Table 9. compressive strength versus different percentage of aluminium powder

\begin{tabular}{|c|c|c|c|c|}
\hline S.no & $\begin{array}{l}\text { aluminium } \\
\text { powder in } \\
\text { percentage }\end{array}$ & $\begin{array}{l}\text { weight } \\
\text { of } \\
\text { cubes } \\
\text { in } \\
\text { grams }\end{array}$ & $\begin{array}{l}\text { dry } \\
\text { density } \\
\text { in }\left(\frac{\mathbf{k g}}{\mathbf{m}^{3}}\right)\end{array}$ & $\begin{array}{l}\text { compressive } \\
\text { strength in } \\
\text { (MPa) }\end{array}$ \\
\hline 1 & 0.05 & 1029 & 989.42 & 12 \\
\hline 2 & 0.05 & 1036 & 977.35 & 11.6 \\
\hline 3 & 0.05 & 989 & 969.6 & 11.8 \\
\hline 4 & 0.1 & 980 & 875 & 9.6 \\
\hline
\end{tabular}

\begin{tabular}{|c|c|c|c|c|}
\hline 5 & 0.1 & 920 & 779.66 & 11 \\
\hline 6 & 0.1 & 1010 & 954.12 & 10.6 \\
\hline 7 & 0.15 & 960 & 744.18 & 8.2 \\
\hline 8 & 0.15 & 1020 & 809.52 & 7.8 \\
\hline 9 & 0.15 & 1060 & 868.85 & 8.8 \\
\hline 10 & 0.2 & 860 & 609.9 & 7 \\
\hline 11 & 0.2 & 950 & 698.5 & 6.8 \\
\hline 12 & 0.2 & 870 & 600 & 6.2 \\
\hline
\end{tabular}

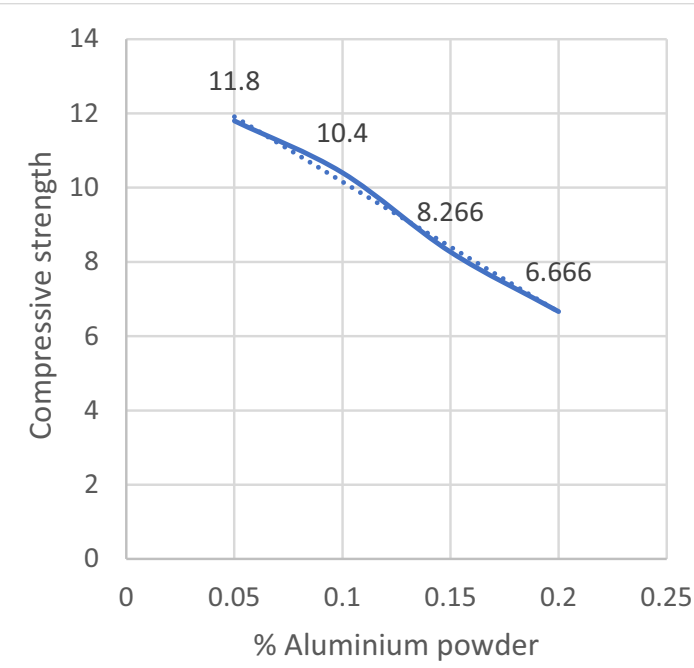

Fig. 7. compressive strength versus aluminium powder

\section{6. conclusions}

1.By the addition of aluminium powder from $0.05 \%$ to $0.2 \%$ of cement, the additional volume of Aerated concrete blocks increased from 30 to 100 percent.

2.Introducing $0.05 \%$ Aluminium powder in aerated concrete, the ultimate compressive strength of $12 \mathrm{MPa}$ is achieved.

3.Compressive strength of aerated concrete is doubled when compared with minimum strength laid in IS 2185 (part-3)-1984 code of density class $800-1000 \frac{\mathrm{kg}}{\mathrm{m}^{3}}$.

4. Best suitable water ratio is 0.4 to $0.45 \%$ of the total mix for better workability and better reactions between materials.

5. The Compressive strength of cubes is depending on both density of the mix and pores distribution in the mix.

\section{REFERENCES}

1. N. Sohani Jani, S. Darshan Shah. Analysis of Microstructure and Properties of AAC Blocks with its Manufacturing Process) Journal of International Academic Research for Multidisciplinary, Volume-2, issue-7(August 2014)

2. O. Shweta Rathi, P.V. Khandve. AAC block-A New eco-friendly Material for Construction) International Journal of Advance Engineering and Research Development, Volume-2, Issue-4(April 2015)

3. Anurag Wahane. Manufacturing Process of AAC Block) IJARSE, Volume No-06, Special Issue No. (02), (September 2017) 
4. Dr. G.V.V. Satyanarayana et al., Experimental Investigation on Foam Concrete with Partial Replacement of Fine Aggregate by Fly ash and Cement by Alccofine) E3S Web of Conferences 184, 01089(2020)

5. Tony Thattil et al., Study on the Properties of Aerated Concrete Incorporating Fly Ash and Quarry Dust) Global Research and Development Journal for Engineering, Volume-2, Issue-5(April 2017)

6. B. Satish Kumar, R. Sukumar et al., Experimental Analysis of Aerated Concrete Block) International Journal of Engineering Research and Technology, Volume-6, Issue-05(May 2017)

7. J. Srinu Naik, V. Chandana et al., Study and Experimentation of AAC by using Fly Ash) International Journal of Innovative Science and Research Technology, Volume-3, Issue-4(April 2018)

8. D. Manikandan, Dr.S. Gopalakrsihnan. A Detailed Study on AAC) International Research Journal of Engineering and Technology, Volume-05, Issue-04(April 2018)

9. Jagadish Vengala, Shivakumar Mangloor et al., Performance of AAC Blocks under Varying Temperature)

International Journal of Recent Technology and Engineering, Volume-7, Issue-6C2, (April 2019) 